\title{
Assessing soil quality and soil erosion hazards in the Moneragala District, Sri Lanka
}

\author{
K. H. K. Perera ${ }^{1}$ - W. A. C. Udeshani ${ }^{2}$ - I. D. U. H. Piyathilake ${ }^{2}$ D . G. E. M. Wimalasiri ${ }^{3}$ ' H. K. Kadupitiya ${ }^{4}$. \\ E. P. N. Udayakumara ${ }^{1}$ (D. S. K. Gunatilake ${ }^{1}$ (D)
}

Received: 1 September 2020 / Accepted: 19 November 2020 / Published online: 9 December 2020

(c) Springer Nature Switzerland AG 2020

\begin{abstract}
This study was carried out in order to assess physicochemical properties of soil and to develop a predictive soil erosion hazard zonation map based on the Integrated Valuation of Ecosystem Services and Tradeoffs (InVEST) - sediment delivery ratio model (SDR) of the Moneragala District which has been recognized as a highly spreading district of chronic kidney disease of uncertain etiology (CKDu) in Sri Lanka. A total of 68 soil samples were purposely collected from cultivation areas from CKDu prevalence and non-prevalence areas representing the entire district in three soil depths of 0-7, 7-14, 14-21 cm using a soil core sampler for the analyses of moisture content and bulk density. Another subset of soil samples was collected from the depths of $0-15,15-30,30-45 \mathrm{~cm}$ for the analysis of $\mathrm{pH}$, electrical conductivity (EC), soil texture, major cations, and heavy metals. According to the results, the soil textural triangle shows that the study area consisted of 11 types of soils and the topsoil layer consisted of mainly 4 soil types as sandy loam soil, sandy clay loam soil, loamy sandy soil, and sandy soil, whereas 52 of the soil samples have belonged to the group of sandy loam. Furthermore, the results disclosed that with the increasing depth, the soil pH and EC are increased, the moisture content is decreased, and bulk density is gradually increased. Fe and $\mathrm{Mg}$ were found to be the dominant cations in the study area, whereas $\mathrm{Cu}, \mathrm{Ni}, \mathrm{Zn}$, and $\mathrm{Pb}$ were within the tolerable limits, whereas $\mathrm{Cd}$ exceeded acceptable levels. Moreover, according to the developed soil erosion hazard zonation map, the predicted mean annual soil loss rate in the study area is $27.8 \mathrm{t} / \mathrm{ha} / \mathrm{yr}$ and a total of $3.7 \mathrm{t} / \mathrm{ha} / \mathrm{yr}$ sediment is exported to the stream by erosion. Moreover, the overall study gives an insight that there is no distinct relationship between the spatial distribution of physicochemical properties and the prevalence of CKDu in the Moneragala District. Moreover, the number of CKDu patients recorded is high in the southern part of the study area where soil erosion is found to be low due to its flat low elevated topography where $71 \%$ of groundwater quality is poor. However, the ultimate outcomes of this study possibly would be directly used for soil and water conservation (SWC) programs in the Monaragala District.
\end{abstract}

Keywords CKDu $\cdot$ Heavy metals $\cdot$ InVEST SDR model $\cdot$ Monaragala district $\cdot$ Soil erosion $\cdot$ Soil properties

S. K. Gunatilake, sksg@appsc.sab.ac.lk; K. H. K. Perera, hiroshan.perera@gmail.com; W. A. C. Udeshani, charitha.udeshani@gmail.com; I. D. U. H. Piyathilake, iduhasantha@gmail.com; G. E. M.Wimalasiri, emadushan@gmail.com; H. K. Kadupitiya, kadupitiya@gmail.com; E. P. N. Udayakumara, udayaepn@gmail.com | ${ }^{1}$ Department of Natural Resources, Sabaragamuwa University of Sri Lanka, P.O. Box 2, Belihuloya, Sri Lanka. ${ }^{2}$ Faculty of Graduate Studies, Sabaragamuwa University of Sri Lanka, P.O. Box 2, Belihuloya, Sri Lanka. ${ }^{3} \mathrm{Crops}$ for the Future Research Centre, Jalan Broga, Kuala Lumpur, Selangor Darul Ehsan, Malaysia. ${ }^{4}$ Natural Resources Management Centre, Peradeniya, Sri Lanka. 


\section{Introduction}

Land degradation is characterized by three main aspects as physical degradation, chemical degradation, and biological degradation [1]. Physical degradation occurs due to soil erosion and deposition; chemical degradation occurs due to contamination of high amount of toxic trace elements, toxic pesticide residues, nitrates, and phosphates. Biological degradation occurs due to organic matter (OM) declination [1]. Soil quality and erosion have threatened the fate of human societies and achieving sustainable development goals which ensure the wellbeing of human and the environment $[2,3]$. The productive capacity of the soil is generally associated with the chemical properties of the soil [4]. Soil erosion is caused by natural agents and anthropogenic activities [5] and it occurs due to water and wind [6, 7]. Climatic variations, high erosive rainfalls, and high erodible soil types are leading natural causative agents for soil erosion $[8,9]$. Rate of soil erosion is induced by anthropogenic activities viz. urbanization, improper land management practices, intensive agricultural practices on steep slopes, and deforestation [10-12]. Soil erosion by water can be considered as one of the most prominent factors of land degradation in Sri Lanka that leads to distress the natural ecosystems and agriculture $[13,14]$. Furthermore, surface mining, urbanization, and construction activities are causative land-use practices that accelerate the natural soil erosion rates [15-17]. The main reason for the accelerated soil erosion is enhancing pressure on fragile ecosystems and lands due to the high increase in population density $[16,18]$. As consequences of induced soil erosion, it removes highly nutritious topsoil that negatively affects the productivity of agricultural lands [19]. However, assessing soil erosion rates is a challenge since the field-based direct and indirect methods of soil erosion assessments are complex and time-consuming [20]. Thus, various soil erosion modeling approaches have been introduced by many researchers to carry out a predictive assessment of soil erosion rates under different conditions [21, 22]. In Sri Lanka, several research studies have been conducted to estimate soil loss rates using various methods [13] by showing that soil erosion is one of the most challenging environmental issues in Sri Lanka [23-27] Furthermore, it has been predictable that approximately $44 \%$ of farming areas in the country are vulnerable to the high soil erosion [28]. Thus, the assessment of erosion hazards with the quality of soil in those areas in Sri Lanka is vital.

In many countries including Sri Lanka, Geographic Information System (GIS)-based soil erosion modeling has been conducted $[29,30]$ using several approaches
[31]. Universal Soil Loss Equation (USLE) and its derivative forms viz. Revised Universal Soil Loss Equation (RUSLE) and InVEST SDR model are the most prominent methods that have been applied in Sri Lanka to predict soil loss rates [23-27]. According to Borselli et al. [32], USLE/ RUSLE-based predictions of soil erosion rates may produce overestimated values of soil erosion rates due to exclusion of the amount of eroded soil reaching catchment outlets [33] further suggested that the integration of the USLE/ RUSLE model with the Sediment delivery ratio at each pixel would be more accurate predictions of soil erosion. Hence, in order to formulate soil erosion hazard map and calculate mean annual soil loss rates in the Moneragala District, USLE-based InVEST-SDR model was used. The InVEST SDR model has been initiated and developed up to the current modifications by Stanford University-USA, the Nature Conservancy (TNC), and the World Wildlife Fund (WWF), working together with many other organizations [34]. The InVEST-SDR model first calculates the quantity of soil that is eroded from each pixel using the RUSLE equation. Thereafter, the Sediment delivery ratio (SDR) of each pixel is calculated. However, Monaragala District was selected for the study since it is one of the most important districts in terms of its hydrological contribution, agriculture, and high prevalence of Chronic Kidney Disease of uncertain etiology (CKDu). This study was conducted to assess the physicochemical properties of soil and to model soil erosion related hazards in the Monaragala District and the findings of this study could be used for formulating soil and water conservation (SWC) policies to combat the present soil erosion in the Monaragala District.

\section{Methodology}

\subsection{Background of the study area}

Monaragala District is located in the Uva province in Sri Lanka with a geographical area of $5,587 \mathrm{~km}^{2}$. It lies at the northern latitudes 6.17" and 7.28" and eastern longitudes $80.50 "$ and 81.35". It is the second-largest district in Sri Lanka with three electoral, namely Monaragala, Bibile, Wellawaya, and 9 Assistant Government Agent (AGA) divisions, namely Bibile, Medagama, Madulla, Badalkubura, Monaragala, Siyambalanduwa, Buttala, Thanamalwila, and Wellawaya (Fig. 1). Also, this land belongs to both dry zone and intermediate zone showing low rainfall and high ambient temperature.

Geologically, the southeastern part of the study area consists of augen gneiss, granitic gneiss with charnockitic appearance. Major structural trends within the area are discontinuous and complex. The boundary zone is 

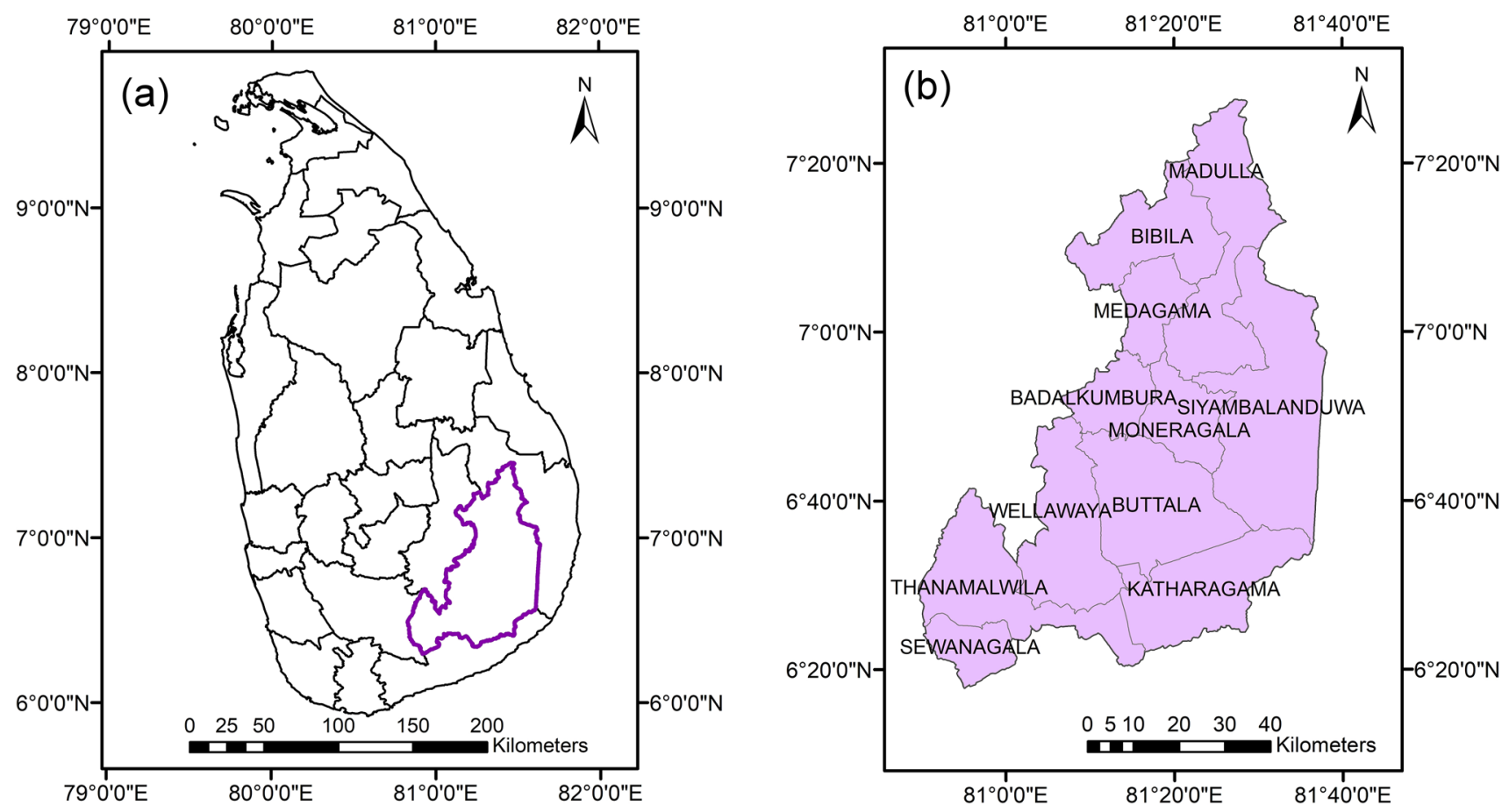

Fig. 1 a Map showing 25 administrative districts in Sri Lanka; b Map showing the Moneragala District

a complex of imbricate, shear, and thrust slices of both Highland Complex (HC) granulites and Vijayan Complex (VC) amphibolite-grade rocks. West of Monaragala District, mylonites vary from protomylonite and coarse-grained augen gneiss to fine-grained ultramylonite. The association of strongly mylonitic rocks along the inferred HC-VC boundary indicates that this is a major tectonic boundary of crustal-scale [35].

Topographically Monaragala District is in a transitional zone from central highland to flat lowland. Concerning the landscape, three terrain types can be identified as highly mountainous terrain, hilly, steep and rolling terrain and undulating and flat terrain with an elevation between 550 and 1400, 160 to 550, and below $150 \mathrm{~m}$, respectively [36]. Based on the topographical and climatic variation, various types of soils can be identified in the Monaragala District. Mainly there are two soil groups namely Reddish Brown Earth (RBE) and Red Yellow Podzolic (RYP) soils in Monaragala District. The RBEs are present in dry and semi-dry intermediate areas, while RYP soils are found in wet and semi-wet intermediate areas (Fig. 2). There are seven river basins drain in the Monaragala District originated from the west-central high lands and flow toward the eastern and southern areas of Sri Lanka. Several drainage basins are covering $80 \%$ of the land area of the district namely as Hedaoya, Walawe, Kirindioya, Kiribbanoya, Wilaoya, Manikganga, and Malalaoya. Only the Walawe river basin is both monsoonal basins [37]. All these river basins have annual
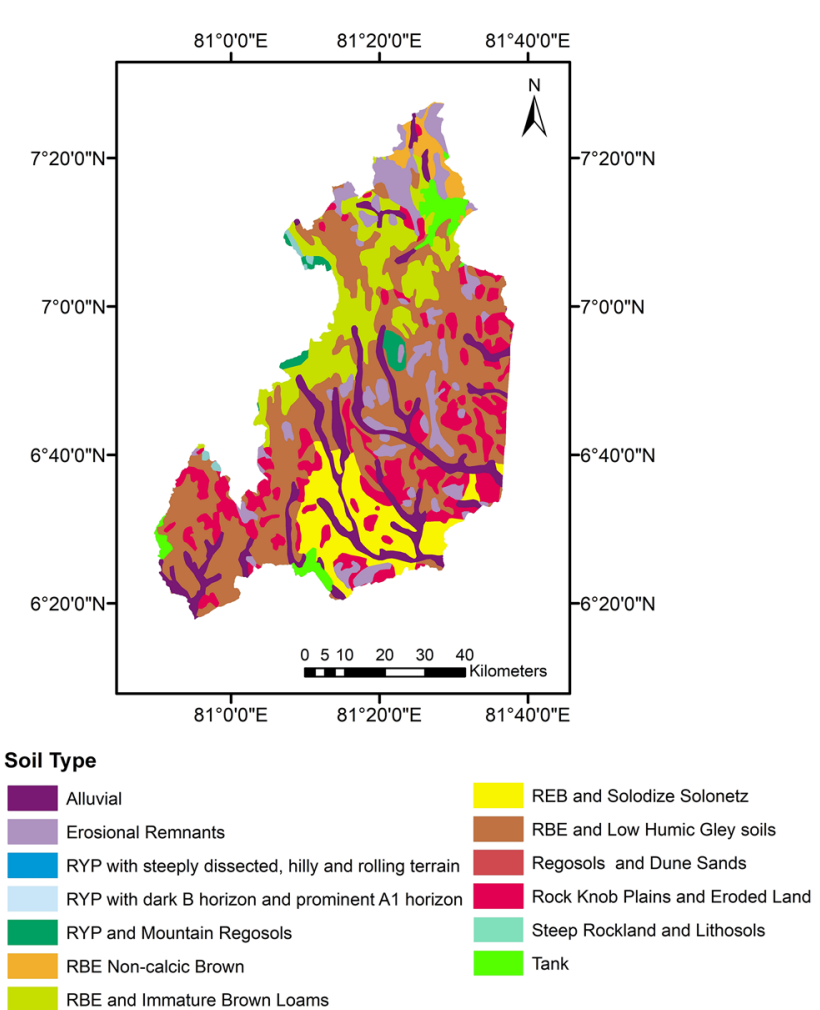

Fig. 2 Map showing variability of soil types in the Moneragala District 
flows with fluctuation levels and volumes depending on the seasonal rains. The dry zone environment of Monaragala District is determined by the seasonal spell of rains, resulting in two rainy seasons namely "Maha" (main) rain season and "Yala" (minor) rain season. The total rainfall of the district ranges from 1328 to $1821 \mathrm{~mm}$ in a year. Over $84 \%$ of rain is received during the seven months of October to January and March to May inclusive. Corresponding to these rainy seasons there are another long and short dry seasons (June-September, and February-March). The low rainfall during these periods and reduction of rainfall in the upper catchment areas will result in frequent drought conditions in a major part of the irrigated area in the Monaragala District. Most of the people in the Monaragala District are engaged in agriculture as their major occupation. Paddy is the main cultivation crop in the area, while vegetables, maize, banana, sugarcane, and several grains are also cultivated in different zones. The natural condition of soil can be changed due to agricultural practices and inputs. In permanent agricultural lands, the soil will be very poor in nutrients [38]. Fertilization is the most common application used by the farmers to overcome this issue.

\subsection{Soil sampling, processing, and storage procedure}

Totally 68 soil samples were collected from recently cultivated (September 2017-November 2018) home gardens, Chena cultivations, and paddy fields representing the entire district (Fig. 3). GPS coordinates of each sampling location were recorded using the handheld GPS device. Two subsets of soil samples were collected from each of the locations representing three different soil depths $(0-7$, $7-14,14-21 \mathrm{~cm})$. One subset of undisturbed soil samples was collected in order to determine soil moisture content and soil bulk density. Other subsets of disturbed soil samples were collected to determine soil $\mathrm{pH}, \mathrm{EC}$, texture, and heavy metals. The collected soil samples were stored in tightly sealed polythene bags until laboratory analyses were conducted.

\subsection{Chemical analysis}

After bringing soil samples into the laboratory, samples were prepared for both wet and dry soil analysis. All visible litter, stones, and coarse roots were removed. Homogeneous soil samples were prepared after sieving through a 2-mm sieve. Field-fresh soil samples were used to analyze $\mathrm{pH}$ and conductivity using a $\mathrm{pH} / \mathrm{EC} / \mathrm{ORP}$ multiparameter. The rest of the soils were air-dried and ground to a powder of less than $0.15 \mathrm{~mm}$ and stored in labeled zip lock bags for dry soil analyses as explained by [39]. Soil samples

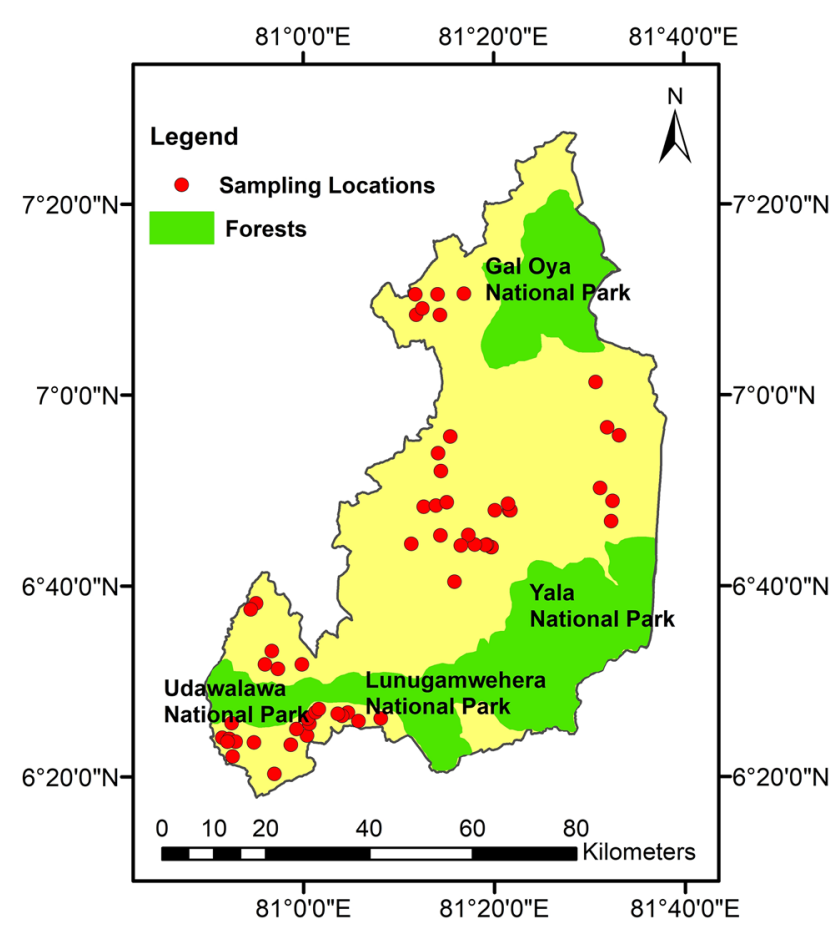

Fig. 3 Map showing the soil sampling locations

were manually digested as explained by [40]. About $5 \mathrm{~g}$ of sieved and dried soil samples was thoroughly ground and approximately about $1 \mathrm{~g}$ of the ground soil samples were placed in a $100-\mathrm{ml}$ beaker for further process. Thereafter, $15 \mathrm{ml}$ of tri-acid $\left(\mathrm{HNO}_{3}: \mathrm{H}_{2} \mathrm{SO}_{4}: \mathrm{HCl}-5: 1: 1\right)$ were added and the content heated gently at low heat on a hot plate for $2 \mathrm{~h}$ at $80^{\circ} \mathrm{C}$ until a transparent solution was obtained. After cooling, the digested sample was filtered using syringe filters. Then, it was diluted to $50 \mathrm{~mL}$ by adding deionized water. Soil samples collected from the first layer were used for the chemical analyses. Major elements $(\mathrm{Na}, \mathrm{K}, \mathrm{Mg}, \mathrm{Ca})$ and trace elements ( $\mathrm{Fe}, \mathrm{Ni}, \mathrm{Zn}, \mathrm{Mn}, \mathrm{Cu}, \mathrm{Pb}, \mathrm{Cd}$ ) of sample extractions were measured using Atomic Absorption Spectrophotometer (AAS) (Varian 240FS). The texture of the soil is determined from the relative composition of sand, silt, and clay in the sample using Granulometry by shaker and hydrometric method.

\subsection{Soil erosion assessment}

In order to assess and map soil erosion in the Moneragala District, a newly introduced and data-intensive InVEST SDR model was applied [41]. As explained by Sharp et al. [41], the InVEST-SDR model uses Universal Soil Loss Equation (USLE) (Eq. 1) in a GIS environment [42], to identify soil loss and amount of sediment that is delivered to downstream. For this purpose, digital elevation model (DEM), rainfall data, soil types map, land use land cover (LULC) 
map, and watershed polygon map were used as key data. Thereafter, as required by the InVEST SDR model software, rainfall-runoff erosivity factor $(R)$ map, soil erodibility $(K)$ map were prepared. Furthermore, crop management factor $(C)$ and support practice factor $(P)$ values for each land use type were obtained by referring to the previously published literature $[13,43]$.

USLE $=R \times K \times L S \times C \times P$

where $R$ is the rainfall erosivity factor (MJ mm (ha hr) ${ }^{-1}$ ) which quantifies the effect of rainfall on the soil erosion [44]. $K$ is the soil erodibility factor ( $\mathrm{t}$ ha $\mathrm{hr}(\mathrm{MJ} \mathrm{ha} \mathrm{mm})^{-1}$ ) which expresses the susceptibility of soil toward erosion process [45]. LS is a slope length-gradient factor (unitless) which represents the effect of the slope's length and steepness on soil erosion [42]. $C$ is a crop management factor (unitless) which is the weighted average of soil loss ratio for a given condition at a given time to that of the unit plot [19]. $P$ is the support practice factor (unitless) which is defined as the ratio of soil loss under a specific soil conservation practice [44].

\subsubsection{Digital elevation model (DEM)}

By using the United States Geological Survey (USGS) Earth Explore, the relevant $30 \mathrm{~m} \times 30 \mathrm{~m}$ grids covering whole Moneragala District were downloaded and merged together to obtain the DEM of the Moneragala District.

\subsubsection{Rainfall-runoff erosivity factor (R) map}

Monthly rainfall data of 30 years (1986-2016) have been collected from the rain gauging stations of the Moneragala District. Thereafter, the mean annual rainfall map was prepared by using the Inverse distance weighting (IDW) Interpolation method in ArcGIS 10.4 mapping software. Ultimately, it was converted into the R factor map using the correlation regression method developed for Sri Lanka by [46] and it was finally converted into a raster map using the Feature to raster tool in ArcGIS.

\subsubsection{Soil erodibility factor (K) map}

After obtaining the soil map of the study area, $\mathrm{K}$ factor values for each soil type were obtained by referring to the previously published literature $[47,48]$. Thereafter, those values were assigned for each soil type and $\mathrm{K}$ factor map was prepared as a raster map.

\subsubsection{Land use land cover (LULC) map with C and P factors}

After obtaining the LULC map of the study area, $C$ and $P$ factor values were obtained referring to the previously published literature $[47,48]$. Ultimately, a biophysical table containing $C$ and $P$ factor values for each LULC type was formulated as input data for running the model [41].

\subsubsection{Watershed map}

By using the DEM of the study area, flow directions and flow accumulation grids were prepared using ArcGIS and it was then converted into a watershed map using the pour point method and Watershed Tool in ArcGIS.

After obtaining all the input map layers and data layers, they were finally integrated by the InVEST SDR model software in order to generate a soil erosion hazard map of the Moneragala District in Sri Lanka. For each cell, the model calculates the quantity of eroded sediment and then it calculated the sediment delivery ratio. The output from this model comprises the sediment load delivered to the stream and the amount of sediment eroded in the catchment at an annual scale.

\section{Results and discussion}

The analytical data for the samples are presented in Table 1. The overall $\mathrm{pH}$ values of layer 1 range from 5.04 to 8.75 , layer 2 ranged from 5.04 to 9.41 and layer 3 ranged from 5.43 to 9.63 , which indicated that the $\mathrm{pH}$ is increased with the depth of the soil layer. Soil pH values specify the alkalinity or acidity condition of the soil based on a scale of $1-14$. The mean $\mathrm{pH}$ values of all three layers of soils and $\mathrm{pH}$ values of $80 \%$ of total soils were below 7.00 showing the acidic condition of the soil in the Monaragala District. Soil $\mathrm{pH}$ affects all biological, chemical, and physical properties of soil [49]. Soil pH may also affect the solubility of salts which directly relate to the EC of soil [50]. As explained by [51], the slightly acidic (6.00-7.00) soil is the most favorable soil for the paddy cultivation which is extensively practiced in the Moneragala District. The alkaline soil is unfavorable for paddy cultivation, because the availability of micronutrients $(\mathrm{Zn}, \mathrm{Cu}, \mathrm{Mg}, \mathrm{P})$ is reduced by alkalinity. Although the mean pH of the study area is below 7.00, $\mathrm{pH}$ of all the soil samples in this study ranged from 5.04 to 9.63 which reveals that the quality of soil ranged from acidic to basic where the addition of lime into the soil is recommended to improve the acidity of the soil for paddy cultivation [51].

Soil EC is the measurement of soluble salt ions in the soil. It associates directly with several soil characteristics viz. soil texture, cation exchange capacity (CEC), soil organic matter content, and salinity [52]. The EC values of the soil samples examine in this study ranged from 11.52 to $613.6 \mu \mathrm{S} / \mathrm{cm}$ in layer $1,8.69-393.9 \mu \mathrm{S} / \mathrm{cm}$ in layer 2 , and $7.63-549.7 \mu \mathrm{S} / \mathrm{cm}$ in layer 3. The most recommended 
Table 1 Physicochemical properties of soil samples

\begin{tabular}{llcccc}
\hline Physicochemical parameters & Layer No. & Mean & SD & Minimum & Maximum \\
\hline $\mathrm{pH}^{*}$ & Layer 1 & 6.52 & 0.67 & 5.04 & 8.75 \\
& Layer 2 & 6.59 & 0.74 & 5.04 & 9.41 \\
& Layer 3 & 6.66 & 0.76 & 5.43 & 9.63 \\
$\mathrm{EC} *(\mathrm{SS} / \mathrm{cm})$ & Layer 1 & 63.40 & 79.18 & 11.52 & 613.6 \\
& Layer 2 & 63.37 & 77.2 & 8.69 & 393.9 \\
& Layer 3 & 65.54 & 101.2 & 7.63 & 549.7 \\
Moisture content ${ }^{* *}(\%)$ & Layer 1 & 19.13 & 15.54 & 1.97 & 87.93 \\
& Layer 2 & 18.09 & 11.4 & 1.73 & 52.50 \\
& Layer 3 & 17.70 & 12.15 & 1.95 & 67.59 \\
Bulk density** $\left(\mathrm{g} / \mathrm{cm}^{3}\right)$ & Layer 1 & 1.32 & 0.28 & 0.56 & 1.99 \\
& Layer 2 & 1.35 & 0.25 & 0.90 & 1.93 \\
& Layer 3 & 1.37 & 0.28 & 0.77 & 2.15 \\
\hline
\end{tabular}

${ }^{*} \mathrm{pH}, \mathrm{EC}$ : layer 1- $(0-15 \mathrm{~cm})$, layer 2-(15-30 cm), layer 3- $(30-45 \mathrm{~cm}) ;{ }^{* *}$ Moisture content, Bulk density: layer $1-(0-7 \mathrm{~cm})$, layer $2-(7-14 \mathrm{~cm})$, layer $3-(14-21 \mathrm{~cm})$ value of soil of EC for cultivation purposes is $<1.0 \mathrm{dS} / \mathrm{m}$ [50] and the EC values of the study area can be recommended for paddy cultivation.

Bulk density can be defined as the soil dry weight of a unit volume. It is generally expected to less than the particle density of soil and it is more likely directly related to the soil texture [53]. Sandy soils generally have higher bulk density than fine-textured soil. As shown in Table 1, the bulk density of the soils studied in this study was found to have the range from 0.56 to $2.15 \mathrm{~g} \mathrm{~cm}^{-3}$. The bulk density of layer 1 ranged from 0.56 to $1.99 \mathrm{~g} \mathrm{~cm}^{-3}$, layer 2 ranged from 0.90 to $1.93 \mathrm{~g} \mathrm{~cm}^{-3}$ and layer 3 ranged from 0.77 to $2.15 \mathrm{~g} \mathrm{~cm}^{-3}$. As explained by [51], the most favorable range of bulk density values for better paddy cultivation is 1.23 to $1.50 \mathrm{~g} \mathrm{~cm}^{-3}$. Thus, the recorded mean bulk density $\left(\sim 1.35 \mathrm{~g} \mathrm{~cm}^{-3}\right)$ of the study area shows the suitability of the soil for paddy cultivation.

Moreover, since the study area located in a range of altitudes (Fig. 4), the spatial distribution maps of soil properties were prepared for soil $\mathrm{pH}, \mathrm{EC}$, moisture content, and bulk density using IDW Interpolation tool in ArcGIS 10.4 (Figs. 5, 6, 7, 8). However, it is visually apparent that there is no significant correlation between the spatial distributions of $\mathrm{pH}, \mathrm{EC}$, and bulk density with the elevation.

As far as the soil texture concerned, soil texture shows the proportional abundance of particles of various sizes, such as sand, silt, and clay in the soil. The texture of soil determines the water-holding capacity, permeability, and workability of soil which affects plant growth (Food and Agriculture Organization of the United Nations). According to the soil textural triangle introduced by [54], there are 12 types of soils. Loam soil is considered as the ideal soil for agricultural practices since it is a more or less similar mix of sand, silt, and clay. Further, loamy soil has a comparatively

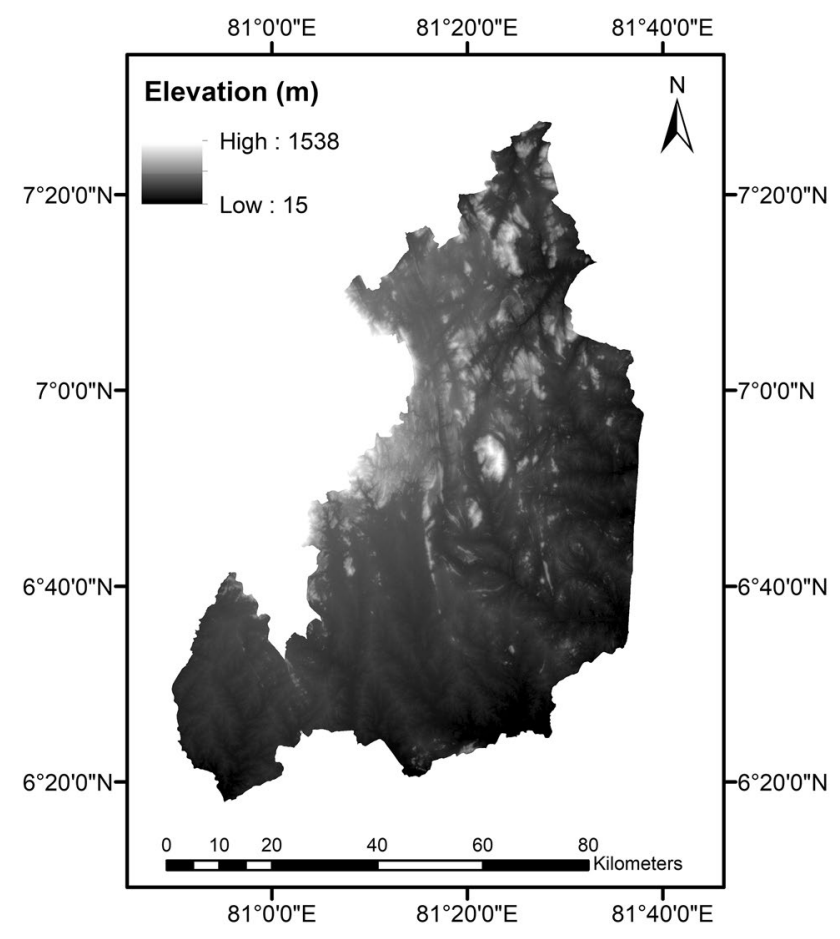

Fig. 4 Digital elevation model of the Moneragala District

high water-holding capacity and sufficient aeration that influence the root growth of plants.

According to the soil textural analysis of soil samples collected from the topsoil layer (in the depth of 0-15 cm), the soil consisted of mainly 4 soil types as sandy loam, sandy clay loam, loamy sand, and sand (Fig. 9). The majority of the soil samples (52\%) belonged to the group of sandy loam.

The cation composition of soil samples collected from the topsoil layer of the study area is summarized 


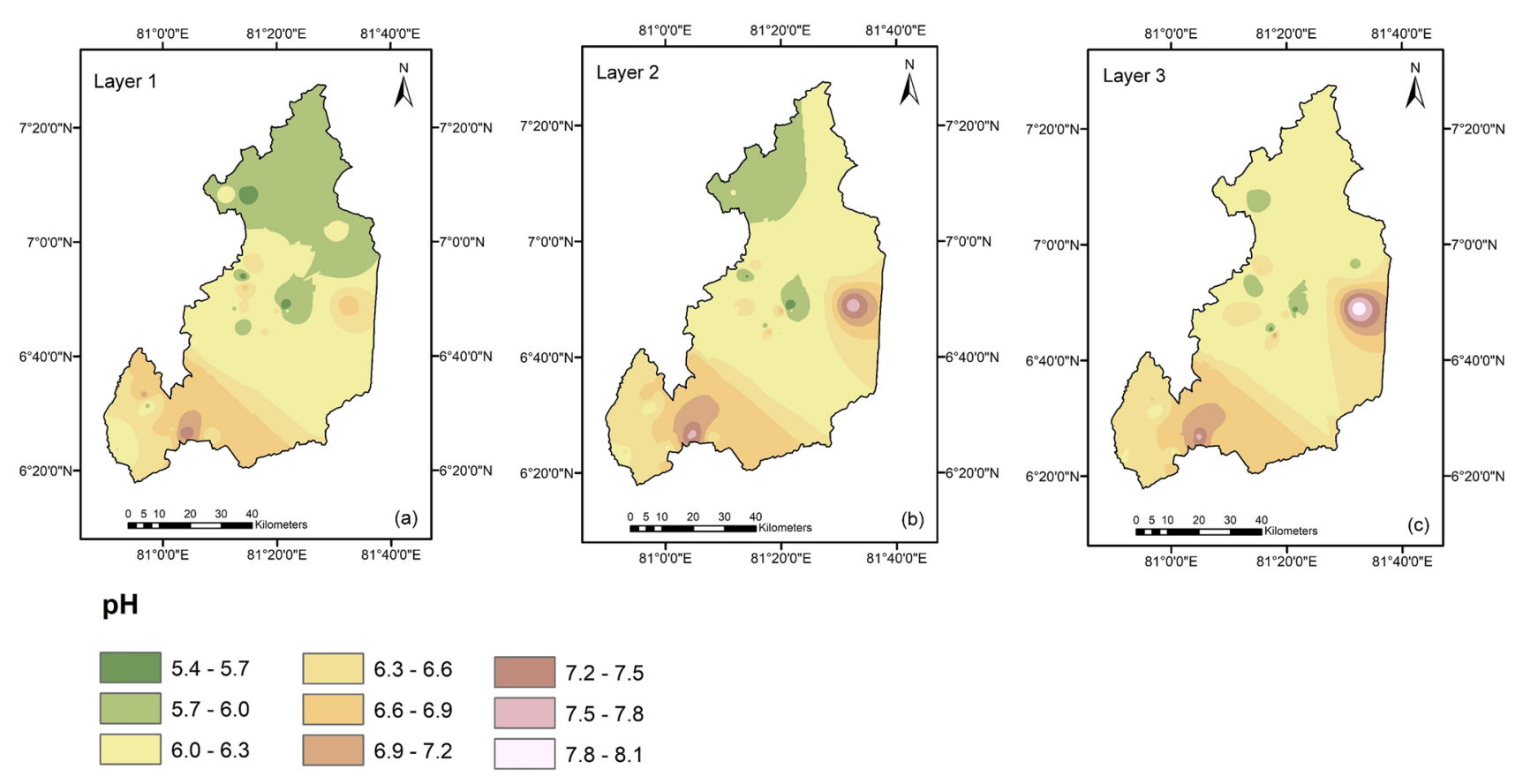

Fig. 5 Map showing the variability of soil $\mathrm{pH}$ in the Moneragala District

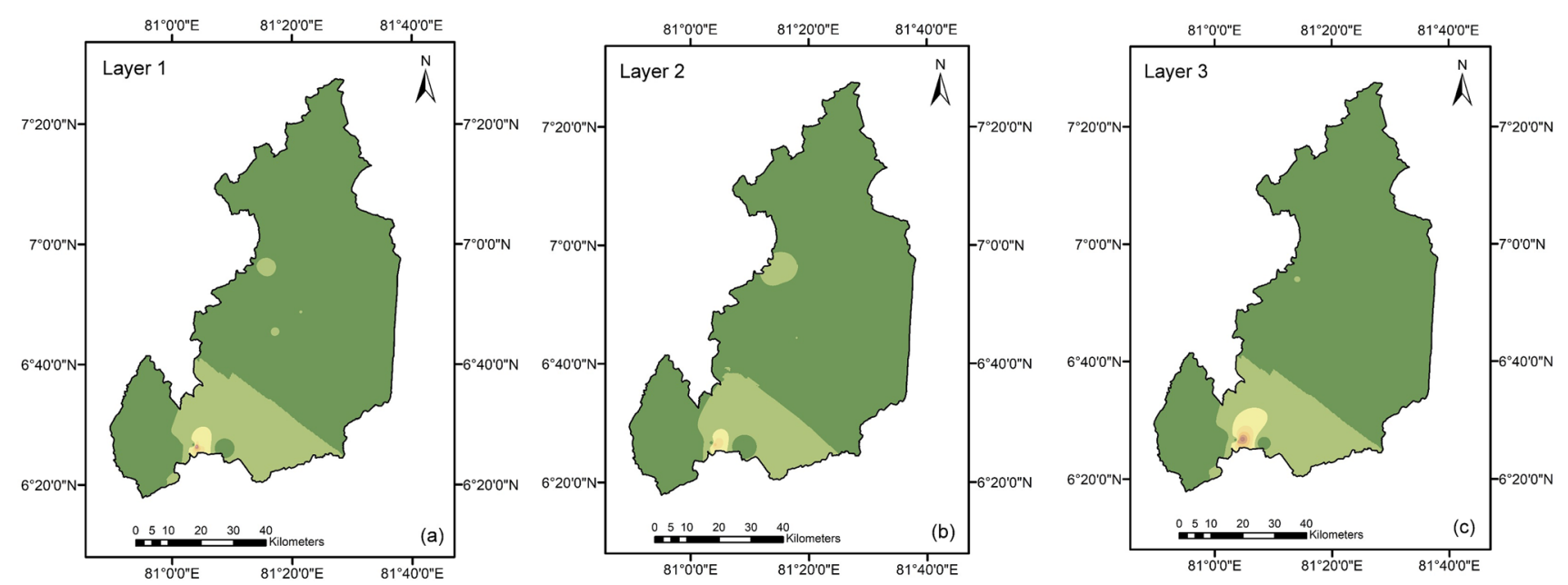

Electrical Conductivity (EC)

\begin{tabular}{|c|c|c|}
\hline $15-90$ & $240-315$ & $465-540$ \\
\hline $90-165$ & $315-390$ & $540-615$ \\
\hline $165-240$ & $390-465$ & $615-690$ \\
\hline
\end{tabular}

Fig. 6 Map showing the variability of soil EC in the Moneragala District

in Table 2. The concentration of Na ranged from 62.5 to $3230.0 \mathrm{mg} / \mathrm{Kg}$ (Mean $=522.5 \mathrm{mg} / \mathrm{Kg}$ ), the concentration of $\mathrm{K}$ ranged from 5.4 to $1840.0 \mathrm{mg} / \mathrm{Kg}$ (Mean $=609.0 \mathrm{mg} / \mathrm{Kg}$ ), the concentration of $\mathrm{Mg}$ ranged from 9.8 to $12,690.0 \mathrm{mg} / \mathrm{Kg}$ Mean $=1809.0 \mathrm{mg} / \mathrm{Kg}$ ), the concentration of Ca ranged from 11.5 to $650.0 \mathrm{mg} / \mathrm{Kg}$ (Mean $=73.0 \mathrm{mg} / \mathrm{Kg}$ ), whereas the mean concentrations of $\mathrm{Fe}, \mathrm{Cr}, \mathrm{Mn}, \mathrm{Zn}$, and $\mathrm{Cu}$ were recorded as 1390.0, $10.0,20.0,10.0$, and $0.13 \mathrm{mg} / \mathrm{Kg}$. It has been reported that paddy farming soil in CKDu endemic area is rich 

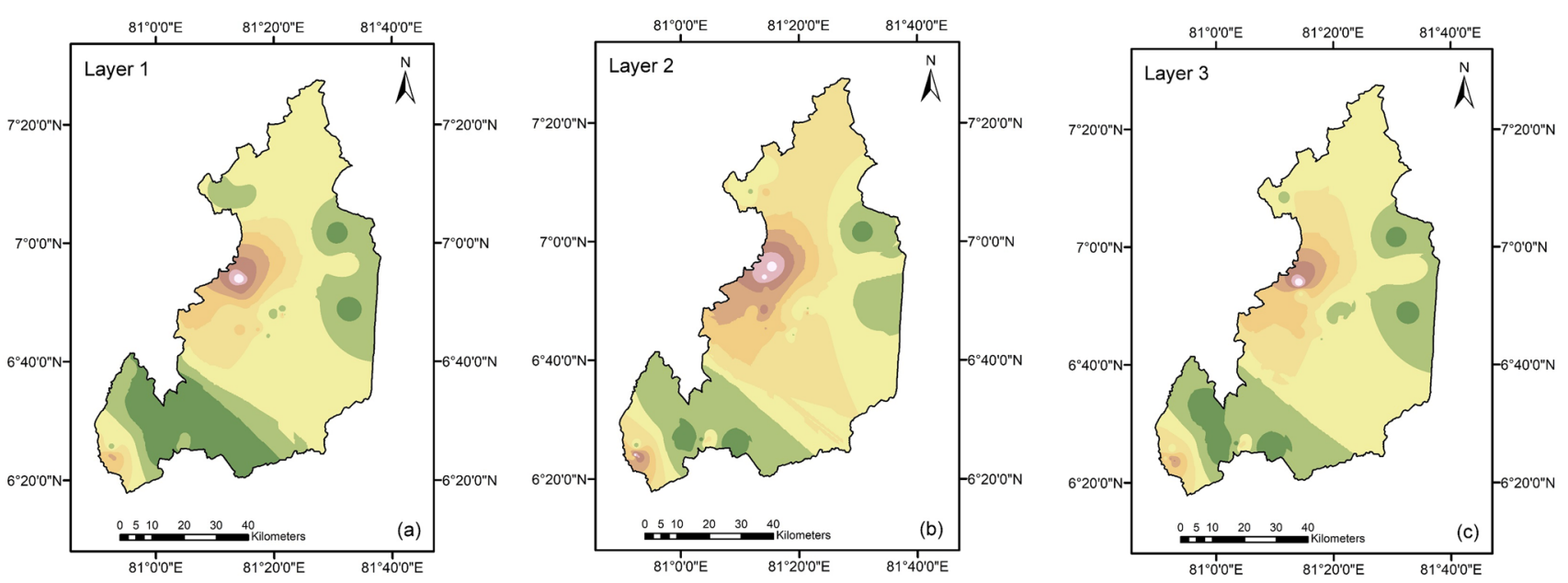

Moisture Content (MC)

\begin{tabular}{|c|c|c|}
\hline $3.5-9.4$ & $21.3-27.2$ & $39.0-45.0$ \\
\hline $9.4-15.3$ & $27.1-33.1$ & $45.0-50.9$ \\
\hline $15.3-21.3$ & $33.1-39.0$ & $50.9-56.8$ \\
\hline
\end{tabular}

Fig. 7 Map showing the variability of soil moisture content in the Moneragala District
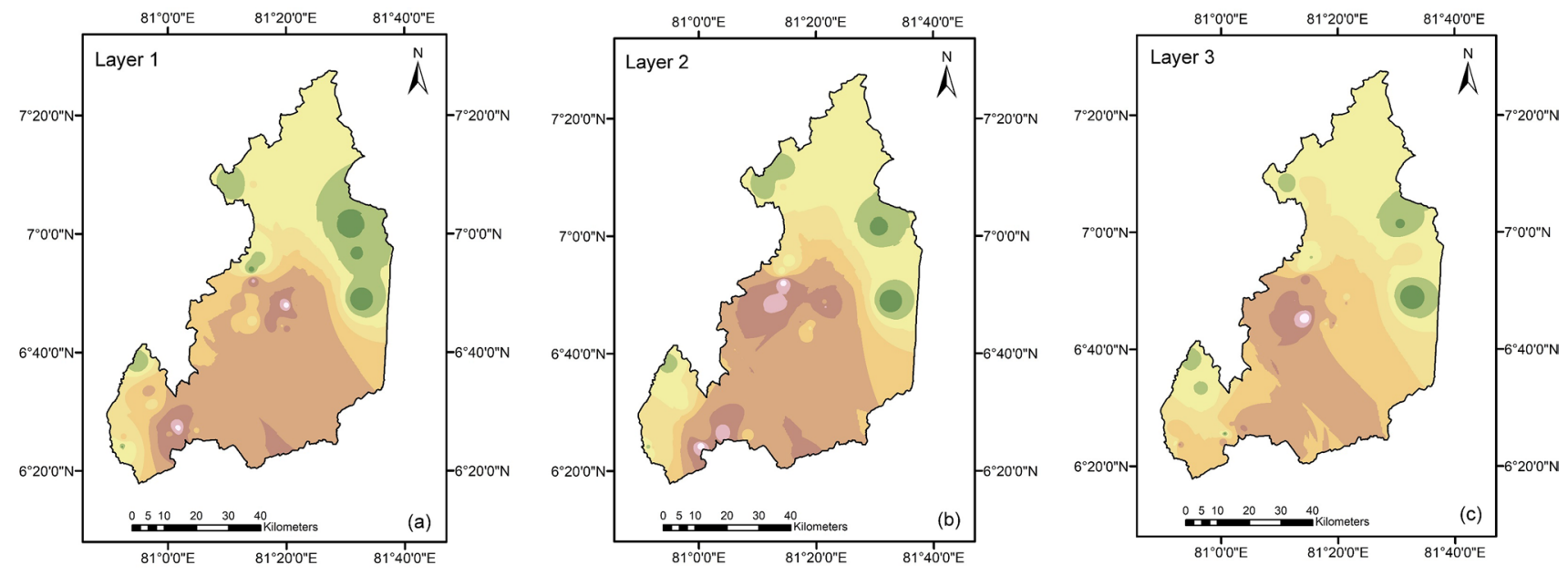

Bulk Density

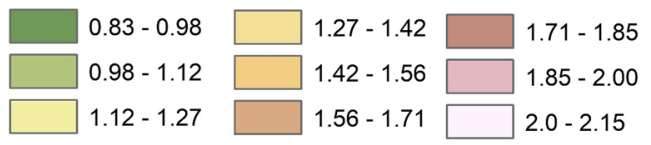

Fig. 8 Map showing the variability of soil bulk density in the Moneragala District

with $\mathrm{Ca}, \mathrm{Mg}, \mathrm{Fe}, \mathrm{Cr}, \mathrm{Ni}, \mathrm{Co}$, and other metals $[55,56]$. In this study, Fe and Mg were the dominant cations, while cations were varied as $\mathrm{Fe}>\mathrm{Mg}>\mathrm{K}>\mathrm{Ca}>\mathrm{Pb}>\mathrm{Na}>\mathrm{Mn}>$ $\mathrm{Zn}>\mathrm{Ni}>\mathrm{Cu}>\mathrm{Cd}$. The concentrations of $\mathrm{Cu}, \mathrm{Ni}, \mathrm{Zn}$, and $\mathrm{Pb}$ were within the tolerable limits, while $\mathrm{Cd}$ exceeded the acceptable limits. This might be occurred due to the excessive applications of agricultural fertilizers viz. Ammonium Sulfate $\left[\left(\mathrm{NH}_{4}\right)_{2} \mathrm{SO}_{4}\right.$ ] Urea $\left(\mathrm{CH}_{4} \mathrm{~N}_{2} \mathrm{O}\right)$, Ammonium Phosphate [[( $\left.\left.\mathrm{NH}_{4}\right)_{3} \mathrm{PO}_{4}\right]$, and Potassium Chloride $(\mathrm{KCl})$ which enhance the mobility of trace heavy metals 
Fig. 9 a Textural triangle of major soil types in the Moneragala District [54]; b Pie chart shows the percentages of soil types

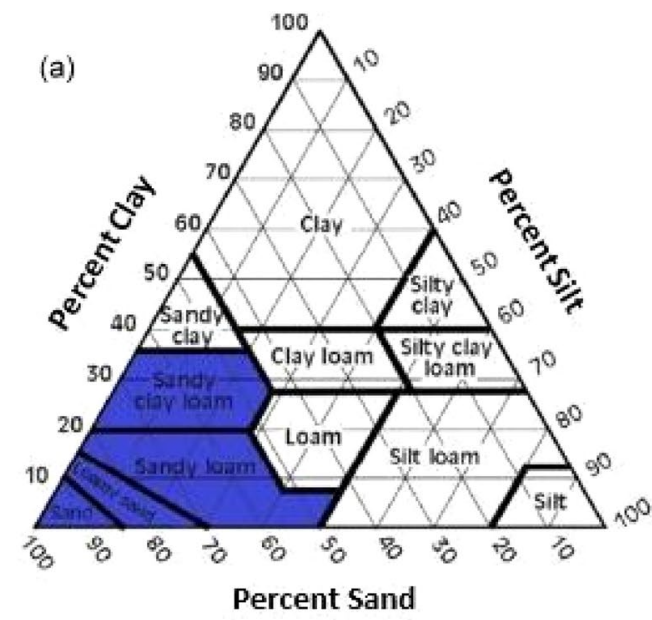

(b)

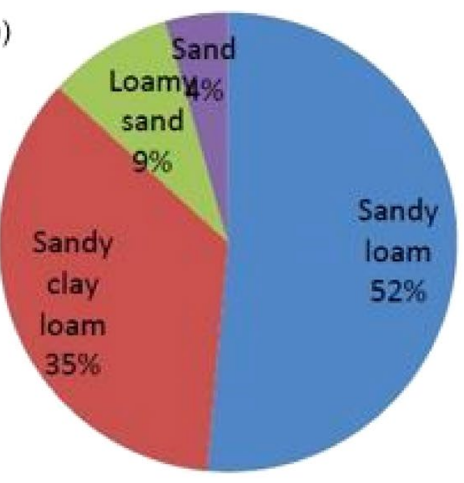

Table 2 Summary of total metal contents of soil samples

\begin{tabular}{|c|c|c|c|c|c|c|}
\hline Cation (mg/kg) & Control (ppm) & Mean & Minimum & Maximum & SD & $\begin{array}{l}\text { Standard } \\
\text { levels } \\
\text { (MPL) }\end{array}$ \\
\hline
\end{tabular}

\begin{tabular}{|c|c|c|c|c|c|c|}
\hline $\mathrm{Cu}$ & 0.001 & 5.42 & 1.15 & 19.15 & 3.12 & $100^{\mathrm{a}}$ \\
\hline $\mathrm{Fe}$ & ND & 2020.18 & 640.00 & 3670.00 & 726.60 & - \\
\hline $\mathrm{Ni}$ & ND & 8.82 & 5.20 & 15.60 & 2.46 & $60^{\mathrm{a}}$ \\
\hline $\mathrm{Zn}$ & ND & 15.42 & 8.60 & 34.00 & 4.42 & $300^{a}$ \\
\hline $\mathrm{Mn}$ & ND & 17.44 & 1.00 & 46.70 & 8.40 & - \\
\hline $\mathrm{Pb}$ & ND & 64.66 & 17.00 & 91.50 & 15.42 & $100^{\mathrm{a}}$ \\
\hline $\mathrm{Cd}$ & ND & 3.03 & 1.70 & 3.65 & 0.40 & $0.6^{\mathrm{b}}$ \\
\hline $\mathrm{Na}$ & 7.60 & 48.52 & 13.70 & 427.95 & 76.20 & - \\
\hline K & 0.601 & 398.95 & 53.90 & 1169.95 & 263.20 & - \\
\hline $\mathrm{Mg}$ & 1.122 & 1322.53 & 277.95 & 2677.15 & 610.00 & - \\
\hline $\mathrm{Ca}$ & ND & 88.48 & 22.45 & 321.85 & 54.60 & - \\
\hline
\end{tabular}

ND Not Detected

${ }^{\text {a }}$ Chary et al. [59], bSEPAC limits [60]
Table 3 Major cation and heavy metal composition in paddy soils in dry zone [61]

\begin{tabular}{llrr}
\hline Cation $(\mathrm{mg} / \mathrm{kg})$ & Min & \multicolumn{1}{c}{ Max } & \multicolumn{1}{c}{ Mean } \\
\hline $\mathrm{Na}$ & 62.5 & 3230.0 & 522.5 \\
$\mathrm{~K}$ & 5.4 & 1840.0 & 609.0 \\
$\mathrm{Mg}$ & 9.8 & $12,690.0$ & 1809.0 \\
$\mathrm{Ca}$ & 11.5 & 650.0 & 73.0 \\
$\mathrm{Fe}$ & 1390.0 & $36,700.0$ & $17,386.0$ \\
$\mathrm{Cr}$ & 10.0 & 30.0 & 23.0 \\
$\mathrm{Mn}$ & 20.0 & 820.0 & 283.0 \\
$\mathrm{Zn}$ & 10.0 & 480.0 & 114.0 \\
$\mathrm{Cu}$ & 0.13 & 40.0 & 21.0 \\
\hline
\end{tabular}

[57]. However, when it compared the spatial distribution of heavy metals in topsoil with the CKDu prevalence in the Monaragala District, there was no distinct relationship between them. [55] has analyzed metal concentrations in surface soil samples collected randomly from 0 to $20 \mathrm{~cm}$ depth from the paddy fields, vegetable plots, and home gardens (Table 3). Similarly, Fe and Mg were the dominant cations in dry zone paddy soils of their study. However, it has been mentioned that the $\mathrm{Cd}$ levels in all studied geo-environmental media are within acceptable limits in their study.

Based on several findings, Chandrajith et al. [58] have mentioned that the Triple Super Phosphate (TSP) in Sri Lanka is contaminated with significant amounts of $\mathrm{Cd}, \mathrm{Cr}$, $\mathrm{Ni}$, and $\mathrm{Pb}$. Therefore, the application of TSP in agriculture may cause to increase the metal concentrations in soil. When there are toxic metals in elevated levels on the topsoil layer, they may easily later leach into the groundwater. Further, these toxic metals may accumulate in food crops and enter into living systems leading to various health problems. 


\section{Prediction of soil erosion hazard}

Soil erosion prediction map (RKLS), total soil loss map (USLE), sediment retention map, and sediment export map are the major outcomes obtained from the InVEST SDR model. Table 4 shows the numerical outputs of the InVEST SDR model. As explained by [41], the RKLS is calculated by only considering rainfall-runoff erosivity factor, soil erodibility factor, and slope length-gradient factor excluding crop management factor and support practice factor which are directly related to the current land-use scenarios. Therefore it can be considered as equivalent to soil loss in bare soil. According to the RKLS map (Fig. 10a), the mean soil erosion potential of the study area is 937.9 t/ha/yr. The USLE map (Fig. 10b) predicts the total amount of soil loss occurred by incorporating the $\mathrm{C}$ and $\mathrm{P}$ factors following the Universal Soil Loss Equation. According to the results, the mean annual soil loss of the Moneragala District is $27.8 \mathrm{t} / \mathrm{ha} / \mathrm{yr}$.

According to Fig. 5, Bibila, Medagama, Madulla, and Badalkumbura area showed a high rate of soil erosion than the other areas in the Monaragala District. Also, previous studies have mentioned that Madagama, Bibila, Alupotha, Idambuwa areas in the Moneragala District are fallen into extremely higher erosion hazards category, which is nearly 9\% of the total land area of the district. Reddish Brown Earths and Immature Brown Loams are the predominant soils in these areas which are somewhat vulnerable to erosion. However, most of these areas consist of home gardens, shrubs, and open forest areas and this land uses may have lessened the impact of soil erosion. Most of the Chena cultivations in these areas belong to the high erosion hazard category of lands. However, low and moderate erosion hazard categories are high in Moneragala District due to the combined effect of forest cover, protected wildlife areas coupled with moderate terrain conditions [12].

Soil loss is a phenomenon that happens naturally and that can be accepted under certain limits. The tolerable soil loss rate is referred to as allowable soil loss $(T)$ and the amount of soil loss that can occur is less than or equal to the natural soil formation rate [62]. However, the $T$ value may differ from place to place. A research that was recently conducted in more or less

Table 4 Numerical outcomes of the InVEST SDR model (t/ha/yr)

\begin{tabular}{llcrr}
\hline Map & Min & Max & Mean & \multicolumn{1}{c}{ SD } \\
\hline Soil loss (USLE) & 0 & $21,354.5$ & 27.8 & 157.4 \\
Soil loss (RKLS) & 0 & $372,148.3$ & 937.9 & 3005.5 \\
Sediment retention & 0 & $199,445.4$ & 226.2 & 980.9 \\
Sediment export & 0 & 8013.6 & 3.7 & 29.5 \\
\hline
\end{tabular}

similar geographical regions has established a permissible rate of soil erosion, ranging from 5 to $10 \mathrm{t} / \mathrm{ha} / \mathrm{yr}$ [63]. Moreover, by using the method of cosmogenic nuclides $\left({ }^{10} \mathrm{~B}\right)$, Hewawasam et al. [64] estimated that the natural soil generation rate in the Upper Mahaweli Watershed in Sri Lanka ranged from 0.13 to $0.30 \mathrm{t} / \mathrm{ha} /$ yr. The current soil loss rate in the Monaragala District is roughly 93-214 times faster than the natural soil generation rate, according to the current study. This is due to clearance of forest covers, improper land management practices, and replacing paddy cultivations with some soil erosion induced cash crops, viz. tomato, cucumber, pumpkin, brinjal, maize, sugar cane, etc. in order to formulate soil and water conservation programs and policies in the Moneragala District, these findings can be taken as baseline information.

Mainly it can be believed that soil erosion is higher in upper areas in the district and this eroded soil may be deposited in lower areas in the southern part of the district. Spatial distribution of CKDu patients is higher in the southern part may be correlated with the higher deposition of dissolved solids in groundwater in the district. The groundwater quality is poor (71\%) in the southern part of the district due to the accumulation of total dissolved solids due to rapid soil erosion in the upper part of the district.

\section{Conclusions and recommendations}

$\mathrm{pH}, \mathrm{EC}$, and bulk density of soil were increased with the depth of the soil layer, while moisture content was decreased and there was no significant difference in any parameter between different layers. The soil texture of the area was categorized into four groups as sandy loam, sandy clay loam, loamy sand, and sand. The majority of the soil samples (52\%) belonged to the group of sandy loam. According to the mean values, Fe and Mg were the dominant cations in the top layer of soil in the study area. Considering toxic heavy metal concentrations, $\mathrm{Cu}, \mathrm{Ni}, \mathrm{Zn}$, and $\mathrm{Pb}$ were within the tolerable limits, while $\mathrm{Cd}$ exceeded. When it compared to the spatial distribution of heavy metals in topsoil with the CKDu prevalence in the Monaragala District, there was no distinct relationship between them. Furthermore, the mean annual soil loss in the study area is $27.8 \mathrm{t} / \mathrm{ha} / \mathrm{yr}$ and if farmers ignore the proper crop management and soil conservation practices, potential soil loss would reach $937.9 \mathrm{t} / \mathrm{ha} / \mathrm{yr}$. However, the sediment delivery amount to the stream is approximately of $3.7 \mathrm{t} / \mathrm{ha} / \mathrm{y}$. The soil erosion is high in the upper part of the district and higher deposition of eroded soil in the lower part (southern part) of the district had been directly correlated with poor groundwater quality in the southern part. Also, the 


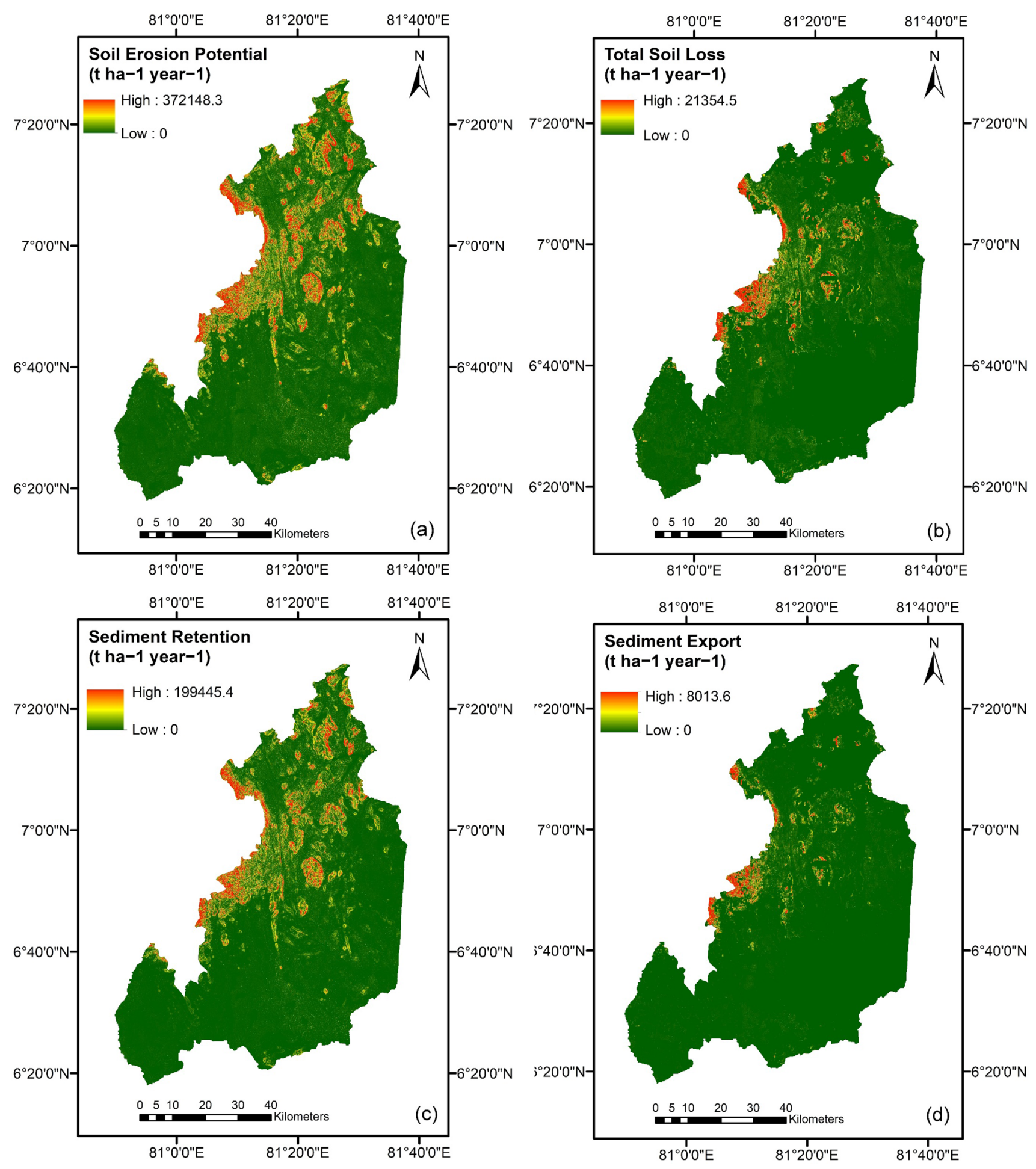

Fig. 10 a Map showing the soil erosion potential (RKLS); b Map showing the total soil loss (USLE); c Map showing the sediment retention; d Map showing the sediment export

number of CKDu patients recorded is high in the southern part, while soil erosion is low due to flat lowland and where $71 \%$ of groundwater quality is poor
Acknowledgements Financial support received by the Sabaragamuwa University of Sri Lanka under the Grant Number SUSL/ RG/2016/13 is highly appreciated. 


\section{Compliance with ethical standards}

Conflict of interest The authors declare that there is no conflict of interest.

\section{References}

1. Keesstra S, Mol G, De Leeuw J, Okx J, De Cleen M, Visser S (2018) Soil-related sustainable development goals: four concepts to make land degradation neutrality and restoration work. Land 7(4):133

2. Keesstra SD, Bouma J, Wallinga J, Tittonell $P$, Smith $P$, Cerdà $A$, Montanarella L, Quinton JN, Pachepsky Y, Van Der Putten WH (2016) The significance of soils and soil science towards realization of the United Nations Sustainable Development Goals. Soil 2:111-128

3. Visser S, Keesstra S, Maas G, De Cleen M (2019) Soil as a basis to create enabling conditions for transitions towards sustainable land management as a key to achieve the SDGs by 2030. Sustainability 11(23):6792

4. Cihacek L, Swan J (1994) Effects of erosion on soil chemical properties in the north central region of the United States. J Soil Water Conserv 49(3):259-265

5. Karchegani PM, Ayoubi S, Lu SG, Honarju N (2011) Use of magnetic measures to assess soil redistribution following deforestation in hilly region. J Appl Geophys 75(2):227-236

6. Feizi Z, Ayoubi S, Mosaddeghi MR, Besalatpour AA, Zeraatpisheh $M$, Rodrigo-Comino J (2019) A wind tunnel experiment to investigate the effect of polyvinyl acetate, biochar, and bentonite on wind erosion control. Arch Agron Soil Sci 65(8):1049-1062

7. Issaka S, Ashraf MA (2017) Impact of soil erosion and degradation on water quality: a review. Geol, Ecol, Landsc 1(1):1-11

8. Bayat F, Monfared AB, Jahansooz MR, Esparza ET, Keshavarzi A, Morera AG, Fernández MP, Cerdà A (2019) Analyzing long-term soil erosion in a ridge-shaped persimmon plantation in eastern Spain by means of ISUM measurements. CATENA 183:104176

9. Cerdà A, Rodrigo-Comino J (2020) Is the hillslope position relevant for runoff and soil loss activation under high rainfall conditions in vineyards? Ecohydrol Hydrobiol 20(1):59-72

10. Keesstra $S$ (2007) Impact of natural reforestation on floodplain sedimentation in the Dragonja basin, SW Slovenia. Earth Surf Proc Landf: J Br Geomorphol Res Group 32(1):49-65

11. Keesstra S, Nunes J, Novara A, Finger D, Avelar D, Kalantari Z, Cerdà $A$ (2018) The superior effect of nature based solutions in land management for enhancing ecosystem services. Sci Total Environ 610:997-1009

12. Senanayake $S$, Munasinghe $M$, Wickramasinghe W (2013) Use of erosion hazard assessments for regional scale crop suitability mapping in the Uva Province. Ann Sri Lanka Dep Agric 15:127-141

13. Piyathilake IDUH, Sumudumali RGI, Udayakumara EPN, Ranaweera LV, Jayawardana JMCK, Gunatilake SK (2020) Modeling predictive assessment of soil erosion related hazards at the Uva province in Sri Lanka. Model Earth Sys Environ. https:// doi.org/10.1007/s40808-020-00944-1

14. Udayakumara E, Shrestha R, Samarakoon L, Schmidt-Vogt D (2012) Mitigating soil erosion through farm-level adoption of soil and water conservation measures in Samanalawewa Watershed, Sri Lanka. Acta Agric Scandinavica, Sect B-Soil Plant Sci 62(3):273-285

15. Cheng $X$, Chen L, Sun R, Kong $P$ (2018) Land use changes and socio-economic development strongly deteriorate river ecosystem health in one of the largest basins in China. Sci Total Environ 616:376-385

16. Diyabalanage S, Samarakoon K, Adikari S, Hewawasam T (2017) Impact of soil and water conservation measures on soil erosion rate and sediment yields in a tropical watershed in the Central Highlands of Sri Lanka. Appl Geogr 79:103-114

17. Premalal $R$ (1986) Development of an erosivity map for Sri Lanka. A Research Report Submitted for the BSc Degree, Department of Agricultural Engineering, University Peradeniya, Kandy, Sri Lanka

18. Lal R (2003) Soil erosion and the global carbon budget. Environ Int 29(4):437-450

19. Jayasekara M, Kadupitiya $H$ (2018) Mapping of soil erosion hazard zones of Sri Lanka. Trop Agric Res 29(2):135-146

20. Taghizadeh-Mehrjardi R, Bawa A, Kumar S, Zeraatpisheh M, Amirian-Chakan A, Akbarzadeh A (2019) Soil erosion spatial prediction using digital soil mapping and RUSLE methods for big sioux River watershed. Soil Sys 3(3):43

21. Ganasri B, Ramesh H (2016) Assessment of soil erosion by RUSLE model using remote sensing and GIS-A case study of Nethravathi Basin. Geosci Front 7(6):953-961

22. Rawat KS, Mishra AK, Bhattacharyya R (2016) Soil erosion risk assessment and spatial mapping using LANDSAT-7 ETM+, RUSLE, and GIS-a case study. Arab J Geosci 9(4):288

23. Jayarathne K, Dayawansa N, De Silva R (2010) GIS based analysis of biophysical and socio-economic factors for land degradation in Kandaketiya DS division. Trop Agric Res 21(4):361-367

24. Nayakekorala $\mathrm{H}$ (1998) Human induced soil degradation status in Sri Lanka. J Soil Sci Soc Sri Lanka 10:1-35

25. Wickramasinghe A (1988) Impact of land use practices on environment conditions of the hill country of Sri Lanka. Sri Lanka J Soc Sci 11:95-113

26. Wijesekara S, Samarakoon L (2002) Application of a soil erosion model in a grid-based GIS environment. Asian J Geo Inf 3(1):49-54

27. Wijesekera N, Chandrasena K (2001) Calibration of a GIS based Watershed Model to Identify Priority Zones for Soil Conservation. CD of Prric-settings of the Asia G15'2001 S_vmp0.।" iurn. Center for Spatial Information Science, University of Tokyo, 5-15, Kashiwanoha, Chiba 277-8568, Japan

28. Wijesundara N, Abeysingha N, Dissanayake D (2018) GIS-based soil loss estimation using RUSLE model: a case of Kirindi Oya river basin, Sri Lanka. Model Earth Sys Environ 4(1):251-262

29. Kothyari UC, Jain SK (1997) Sediment yield estimation using GIS. Hydrol Sci J 42(6):833-843

30. Priya S, Shibasaki R (1998) Quantification of Soil Loss and its Prediction using GIS and Remote Sensing Technology. Asian-Pac Remote Sens J 10(2):33-38

31. Breiby T (2006) Assessment of soil erosion risk within a subwatershed using GIS and RUSLE with a comparative analysis of the use of STATSGO and SSURGO soil databases. Pap Res Anal 8:1-22

32. Borselli L, Cassi P, Torri D (2008) Prolegomena to sediment and flow connectivity in the landscape: a GIS and field numerical assessment. CATENA 75(3):268-277

33. Borselli $L$ (2015) Sediment connectivity and travel times: concepts and applications. In: Summer School on Geomorphology: Sediment dynamics in high-mountain environments, Feichten im Kaunertal, Austria. http://dx.doi.org/10.13140/RG.2.2.29760 .53761

34. Udayakumara EPN, Gunawardena UADP (2016) Reducing Siltation and Increasing Hydropower Generation from the Rantambe Reservoir, Sri Lanka, No.111

35. Harris NB (1991) Cooray PG (1984) An Introduction to the Geology of Sri Lanka (Ceylon), xix+340pp, Colombo, National Museums of Sri Lanka. Geol Mag 128(1):85 
36. Cooray PG (1967) An introduction to the geology of Ceylon. National Museums of Ceylon Publication, Colombo, pp 176-184

37. Arumugam S (1969) Water resources of Ceylon its utilization and development. Water Resources Board publications, Colombo, Sri Lanka, p 415

38. Savci S (2012) An agricultural pollutant: chemical fertilizer. Int J Environ Sci Develop 3(1):73

39. Anderson J, Ingram J (1993) A handbook of methods. CAB International, Wallingford, Oxfordshire, $p 221$

40. Allen S, Grimshaw H, Rowland A (1986) Chemical analysis Methods in Plant Ecology. Blackwell Scientific Publications, Oxford

41. Sharp R (2018) InVEST User's Guide -InVEST 3.7.0 documentation

42. Wischmeier WH, Smith DD (1978) Predicting rainfall erosion losses: a guide to conservation planning, vol 537. Department of Agriculture, Science and Education Administration

43. Joshua W (1977) Soil erosive power of rainfall in the different climatic zones of Sri Lanka. Eros Solid Matter Trans Inland Waters IAHS Publ 122:51-61

44. Renard KG, Foster GR, Weesies G, McCool D, Yoder D (1997) Predicting soil erosion by water: a guide to conservation planning with the Revised Universal Soil Loss Equation (RUSLE), vol 703. United States Department of Agriculture Washington, DC

45. Sharma A (2010) Integrating terrain and vegetation indices for identifying potential soil erosion risk area. Geo-Spatial Inf Sci 13(3):201-209

46. Wickramasinghe $L$, Premalal $R$ Development of a rainstorm erosivity map for Sri Lanka. In: Proc of the 5th International Soil Conservation Conference. Ed. Sanam Rimwanich. Bangkok, Thailand, 1988

47. Fayas CM, Abeysingha NS, Nirmanee KGS, Samaratunga $D$, Mallawatantri A (2019) Soil loss estimation using rusle model to prioritize erosion control in KELANI river basin in Sri Lanka. Int Soil Water Conserv Res 7(2):130-137

48. Mapa R, Somasiri S, Dassanayake A (2010) Soils of the Dry zone of Sri Lanka. In: Morphology, Characterization and Classification. Special Publication No7 Soil science society of Sri Lanka

49. Brady N, Weil R (1999) The nature and properties of Soil, 12th edn. Prentice Hall Inc., New Jersey, USA

50. Aizat AM, Roslan M, Sulaiman WNA, Karam DS (2014) The relationship between soil pH and selected soil properties in 48 years logged-over forest. Int J Environ Sci 4(6):1129-1140

51. Rajendran A, Shanmuganathan M (2019) Physico-chemical analysis of soils for the better yield of sugarcane and rice using Heber soil quality index. East African Agric Forestry J 83(3):206-220

52. Farahani H, Buchleiter G, Brodahl M (2005) Characterization of apparent soil electrical conductivity variability in irrigated sandy and non-saline fields in Colorado. Trans ASAE 48(1):155-168
53. Stocking M, Murnaghan N (2001) Handbook for the field assessment of land degradation. Earthscan

54. White RE (1987) Introduction to the principles and practice of soil science. Blackwell Scientific Publications, Oxford, UK, pp 244. ISBN: 063201606X

55. Chandrajith R, Dissanayake CB, Tobschall HJ (2005) The abundances of rarer trace elements in paddy (rice) soils of Sri Lanka. Chemosphere 58(10):1415-1420

56. Jayasumana C, Gunatilake S, Senanayake P (2014) Glyphosate, hard water and nephrotoxic metals: are they the culprits behind the epidemic of chronic kidney disease of unknown etiology in Sri Lanka? Int J Environ Res Publ Health 11(2):2125-2147

57. Khan S, Qureshi M, Singh JB (1996) Studies on the mobility of heavy metals in soil. Indian J Environ Health 38(1):1-6

58. Chandrajith R, Seneviratna S, Wickramaarachchi K, Attanayake T, Aturaliya T, Dissanayake C (2010) Natural radionuclides and trace elements in rice field soils in relation to fertilizer application: study of a chronic kidney disease area in Sri Lanka. Environ Earth Sci 60(1):193-201

59. Chary NS, Kamala C, Raj DSS (2008) Assessing risk of heavy metals from consuming food grown on sewage irrigated soils and food chain transfer. Ecotoxicol Environ Saf 69(3):513-524

60. Chahal V, Chand P, Nagpal A, Kaur K, Pakade Y (2014) Evaluation of heavy metals contamination and its genotoxicity in agricultural soil of Amritsar, Punjab, India. Int J Res Chem Environ (IJRCE) 4(4):20-28

61. Chandrajith R, Ariyaratna T, Dissanayake C (2012) The Status of Cadmium in the Geo-environment of Sri Lanka. Ceylon J Sci (Phys Sci) 16:47-53

62. Udayakumara E, Shrestha R, Samarakoon L, Schmidt-Vogt D (2010) People's perception and socioeconomic determinants of soil erosion: a case study of Samanalawewa watershed, Sri Lanka. Int J Sedim Res 25(4):323-339

63. Jha P, Nitant $H$, Mandal D (2009) Establishing permissible erosion rates for various landforms in Delhi State. India Land Degrad Dev 20(1):92-100

64. Hewawasam T, von Blanckenburg F, Schaller M, Kubik P (2003) Increase of human over natural erosion rates in tropical highlands constrained by cosmogenic nuclides. Geology 31(7):597-600

Publisher's Note Springer Nature remains neutral with regard to jurisdictional claims in published maps and institutional affiliations. 